Journal of Educational Science and Technology

Volume 5 Number 3 December 2019 page 295-302

p-ISSN:2460-1497 and e-ISSN: 2477-3840

DOI: https://doi.org/10.26858/est.v5i3.11008

\title{
The Implementation of Inquiry-Based Learning to Improve the Learning Result of Football
}

\author{
Saharullah $^{1}$, Nur Abidah Idrus ${ }^{2}$, Muhammadong ${ }^{3}$, Reski Arisandy ${ }^{4}$ \\ ${ }^{1}$ Sports Science, Universitas Negeri Makassar, Indonesia \\ Email: ullah_fik@yahoo.com \\ ${ }^{2}$ Elementary School Teacher Education, Universitas Negeri Makassar, Indonesia \\ Email: nurabidah_unm@yahoo.com \\ ${ }^{3}$ Physical Education, Health and Recreation, Universitas Negeri Makassar, Indonesia \\ Email: muhammadong74@yahoo.com \\ ${ }^{4}$ Physical Education, Health and Recreation, Universitas Negeri Makassar, Indonesia \\ Email: ari.shandynamiec@gmail.com
}

(Received: October-2019; Reviewed: October-2019; Accepted: November-2019;

Avalaibel Online: December 2019; Published: December-2019)

This is an open access article distributed under the Creative Commons Attribution License CC-BY-NC-4.0 (2019 by author (https://creativecommons.org/licenses/by-nc/4.0/ ).

\begin{abstract}
The study aimed at improving students' learning outcomes about football through the inquiry learning model at Vocational High School 2 Makassar. Data were collected using PJOK learning result test and observation. The results of recapitulation between cycles after implementing inquiry learning model indicate that football learning outcomes of students in grade X TKJ 1 at Vocational High School 2 Makassar improved, proven by the result in cycle I that $6(17.1 \%)$ out of 35 students were in Moderate scale and only 1 student (2.9\%) was in Poor scale. In cycle II, the learning outcomes improve as there were 10 students (28.6\%) in Moderate scale. Classically, cycle I is stated as unsuccessful because only $74.29 \%$ of students were in the complete category and has not achieved successful indicators which had been determined. In cycle II, there was an improvement of completeness which was stated as successful because $91.43 \%$ of students were in the complete category and has not achieved successful indicator which had been determined, which was $80 \%$. The inquiry learning model applied in teaching football can improve learning outcomes based on the achievement of learning results completeness classically and individually.
\end{abstract}

Keywords: Implementation, inquiry, learning, outcomes, football

\section{INTRODUCTION}

The teaching process frequently orients on how to deliver all material instead of achieving the learning goal which in this case is the improvement of students' competences. Competences include the learning result and independence in learning. Teaching models which have been being applied still tend to be more theoretical and less consider the students' competence. Tamren, (2017: 1)

Physical education refers to learning through physical activities, games, or sports which are chosen to reach the goals of education Rosdiani, (2014:167). This definition 
strengthens that physical education is an inseparable part of general education. The goal is to support students to grow and develop normally based on national education goals: to become a whole Indonesian human being. The achievement of those goals is based on the planning of movement experiences that are appropriate with children's characteristics.

In the learning process conducted at Vocational High School 2 Makassar, there were some problems faced by both teachers and students leading the activities not conducive. The problem, in this case, was the limitation of teaching model variations in delivering the learning materials, especially about football so that students quickly got bored when joining the Physical, Sports, and Health Education. Also, because the material was too monotonous, this subject did not become favorable for students. Another problem was that most students did not give full attention during the learning activities causing them unable to know, master, and understand the materials and did not identify the purpose why the materials of football are taught in that session.

The inquiry model is a strategy to solve students' boredom when studying in the classroom because it creates learning activities focusing on students instead of the teacher. The inquiry is a development from discovery learning which presents mental processes in the higher level like formulating problems, designing experiments, carrying out experiments, collecting and analyzing data, withdrawing conclusion, behaving objectively and honestly, having curiosity, openness, and so on Nurhaida (2016:302)

An inquiry learning model is a systematic approach in the implementation of learning stages that involve all students' learning skills and require them to seek and investigate problems in learning activities, (2017:28).

Besides that, teachers are pushed to be able to plan, execute, and assess the learning to strengthen students' characters by emphasizing five main values which are religious, nationalism, independence, cooperation, and integrity.

The urgency of this research is as academic development material specifically the effect of the implementation of inquiry teaching model on the learning result of football material at Vocational High School 2 Makassar.

This study is expected as input for teachers in applying the good teaching method, especially about football. This study also aimed to be an input for schools to provide guidance or to propose improvements to the learning system or teaching methods for teachers as educators especially in teaching football.

One of the alternatives of learning models that can be applied is the inquiry model. Inquiry as a learning model focuses on the activities of seeking and finding. The material is not directly delivered to students yet students should be active to seek and find the materials that they are going to study by their own Diah (2018: 3)

Learning is defined as the process of changing behavior resulted from an interaction between individuals and their environments Husdarta \& Saputra, (2014:2). The attitude refers to aspects of knowledge, skills, and behaviors. They are divided into 2 groups, observable and unobservable. Attitudes that can be observed are called behavioral performance, while the ones that cannot be observed are called behavioral tendencies. Uneffective learning is the learning that does not bring students to reach any goals of each activity. If the learning activities are only active and fun but not effective, they are only regarded as common games without meaning. Dwi Ambarwati, (2017: 77)

The learning outputs refer to the developments of students' skills, knowledge or attitudes resulting from the learning activities they join Kumpas-Lenk et all, (2018). Basically, learning outputs are results of interactions and various factors that affect the process of learning holistically. Learning with guided inquiry model allows students to directly involve so that they can be motivated to study. Besides that, students are given chances to participate in the learning and the teacher only guides the students. Next, in the learning process in the classroom with the inquiry model, students are freer to find out the concept on their own. In the practicum, students can develop concepts they have built using their own knowledge and information from their friends Yusniati, (2017:5).

This teaching model tries to teach students to identify problems, formulating them, finding out solutions, or testing hypothesis of problems or questions through investigation (finding out facts using their senses), and at the end, they can withdraw conclusions and presenting them orally or written Handayani, (2016:197).

Inquiry learning will allow interaction between facts that students have believed 
already and proves that they have just got to get a better understanding through exploration processes and methods towards the new ideas Rahmawati \& Rina (2017:42)

Scientific approaches give chances to students to actively participate in learning activities. Students who are studying to find out the concept on their own will get more meaningful experiences and the knowledge will be more strongly inherent in their memory. Therefore, the application of a scientific approach with an inquiry learning model can be selected as a teaching model to improve students' learning result Handriani, (2015:217).

The strength of inquiry learning model is that it can help students to develop skills of cognitive process they have mastered, to understand materials more easily and to make them more memorable, to increase their motivation and spirit to study, to give them chances to be more developed based on their ability and interests, and to improve students' confidence through the investigation processes Juniarti Dkk, (2017:51)

Based on the problems above, the researcher emphasized on the topic about the improvement of the learning result of football material using inquiry learning model. The teaching model is designed well to improve the students' learning result in football materials.

The aim of this research, based on the proposed research questions, is to investigate the effect of the application of inquiry learning to the results of studying football of students at Vocational High School 2 Makassar.

Based on the literature review, the hypothesis proposed for this study is that "The application of inquiry learning model can increase the learning results of football materials of students at Vocational High School 2 Makassar. After implementing the stages of inquiry learning, students learning results of football materials at Vocational High School 2 Makassar could be improved.

\section{METHOD}

This is a Classroom Action Research (CAR) with four stages: planning, implementing, observing, and reflecting. Those four activities were carried out through learning cycles Nur Khosiah (2016: 216).

Inquiry learning is a model that can stimulate students to be active in the learning process Aningsi (2018: 52).
Classroom Action Research orients on the implementation of treatment which aim to improve the quality or the problem solving of a group of subjects which are investigated and to observe the success level or the impacts of further actions which act as refinement of actions or adjustments to conditions and situations to obtain a better result Paizaluddin \& Ermalinda, (2014:6).

Broadly speaking, there are four common stages to perform including planning, implementation, observation, and reflection.

The scheme of the action flow is figure 1:

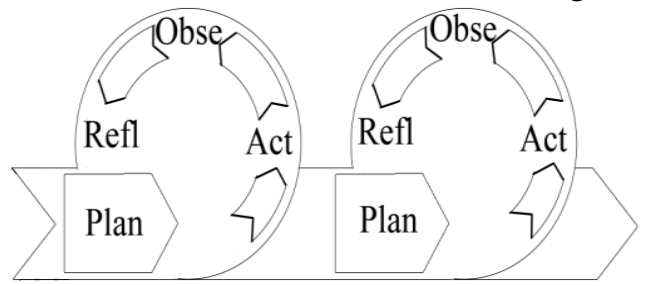

Figure 1. CAR Cycle Source: Kemmis and McTaggart Cycle Model in (Sukardi, 2015:8)

This study was carried out to students at the $10^{\text {th }}$ grade of TKJ Vocational High School 2 Makassar, which was focused on two aspects: The implementation of the inquiry learning model and the learning result of football materials of students at the $10^{\text {th }}$ grade of TKJ, Vocational High School 2 Makassar.

The study was carried out at Vocational High School 2 Makassar. The subjects were the tenth-grade students of TKJ 1 of Vocational High School 2 Makassar in the academic year of $2018 / 2019$. The total number of students was 35 consisting of 28 boys and 7 girls.

To collect data, we carried out some activities including: (a) Test. It is a tool that is used to measure some performances and to collect data Widiastuti, (2017:2). To measure the learning result of football material of students at Vocational High School 2 Makassar through inquiry learning mode, both practice and written tests were utilized; (b) Observation. It was a data collection method that was conducted by watching the learning activities which were being performed; (c) Documentation. It was performed to get data about the learning results of football materials of students at Vocational High School 2 Makassar. Documentation was also carried out to collect the photos of the research activities and students. 
This study was carried out through 4 meetings in 2 cycles. Each meeting was run for 90 minutes.

The data about the improvement of the students' learning results on the topic of Football through the inquiry learning model at Vocational High School 2 Makassar were analyzed quantitatively. Data on the learning result in the first and second cycles were analyzed quantitatively supported with findings from observation. Then, the average score of test or evaluation on the learning result was calculated. The completeness of scores obtained from each cycle is grouped based on score conversion as below table 1:

Table 1. Categories of Score Completeness of Students at Vocational High School 2 Makassar

\begin{tabular}{cc}
\hline Score Intervals & Categories \\
\hline $85-100$ & Very Good \\
$75-84$ & Good \\
$65-74$ & Average \\
$55-64$ & Low \\
$0-54$ & Very Low \\
\hline
\end{tabular}

Then, the table about the classification of the completeness level of students' learning result is as below table 1 .

Table 2. Classification of Completeness of Students at Vocational High School 2 Makassar

\begin{tabular}{ll}
\hline Scores & Categories \\
\hline$>75,00$ & Completed \\
$<75,00$ & Uncompleted \\
\hline
\end{tabular}

\section{RESULT AND DISCUSSION}

\section{Result}

The study was carried out through two cycles, cycles 1 and 2. Each of them was conducted for 3 meetings.

After the implementation of the inquiry learning model on students at Vocational High School 2 Makassar, we obtained the following data. Below is the table of findings of observation on three assessment components of football material learned by students at Vocational High School 2 Makassar after this classroom action research performed.
Table 3. Recapitulation of Description Completeness Scores at Cycle I

\begin{tabular}{clcc}
\hline $\begin{array}{c}\text { Score } \\
\text { Range } \\
\text { s }\end{array}$ & Criteria & $\begin{array}{c}\text { Frequenc } \\
\mathbf{y}\end{array}$ & $\begin{array}{c}\text { Percentag } \\
\mathbf{e}\end{array}$ \\
\hline$>75$ & Completed & 26 & $74,29 \%$ \\
\hline$<75$ & $\begin{array}{l}\text { Uncomplete } \\
\mathrm{d}\end{array}$ & 9 & $25,71 \%$ \\
\hline & Total & 35 & $100 \%$ \\
\hline
\end{tabular}

Based on the table above, the completeness of students' learning results reached $74,29 \%$ and the rests of them who did not complete were $25,71 \%$. From the data obtained after the first cycle, it can be seen that the treatment using the inquiry learning model had brought 26 students to complete the minimum standard criteria while the other 9 students did not complete.

Then, to the categorization of the learning results can be seen in the following table 4:

Table 4. Recapitulation of Description Categorisation at Cycle I

\begin{tabular}{cccc}
\hline $\begin{array}{c}\text { Score } \\
\text { Ranges }\end{array}$ & Categories & Frequency & Percentage \\
\hline $85-$ & Very Good & 6 & $17,1 \%$ \\
100 & Good & 20 & $57,1 \%$ \\
$75-84$ & Average & 8 & $22,9 \%$ \\
$65-74$ & Low & 1 & $2,9 \%$ \\
$55-64$ & Lew & 0 & $0,0 \%$ \\
$0-54$ & Very Low & 35 & $100 \%$ \\
\hline \multicolumn{2}{c}{ Total }
\end{tabular}

Based on the summary of descriptive data presented in the table above, the learning results of students were $74,29 \%$ in the completed category. Students in the score ranges of $85-100$ were $6(17,1 \%)$ and students who were in the good category (75-84) were 20 $(57,1 \%)$, while students in the uncompleted category were $9(25,71 \%)$. The number of students who were in the average category (65$74)$ was $8(22,9 \%)$, and in the low category was only $1(2,9 \%)$. There was no student in the very low category $(0-54)$.

Based on the data of students learning results after studying with the inquiry model in the first cycle, there was an improvement 
compared to the initial observation. In the initial data, there were 8 students in the completed category $(23,00 \%)$ and improved to 26 students $(74,29 \%)$. It means, there is a sudden improvement after 3 meetings. Therefore, it can be concluded that the inquiry learning model that was implemented on learning football in the first cycle at Vocational High School 2 Makassar improved by $51,29 \%$.

In this research, the observation was not only carried out to find out student learning outcomes but also to know the learning process related to student attitudes while participating in learning. Observation sheets were filled out based on the teacher's observation of the researcher. The results of observations of the learning process in the first cycle showed that there were $75 \%$ poor aspects. This is a weakness that occurred in the first cycle and will be taken as a reflective material on the revisions that will be carried out in the second cycle.

Results of Cycle II. The following table presents the data obtained from observation on three assessment components on football material at Vocational High School 2 after carrying out this classroom action research which applied the inquiry learning model in the second cycle.

Table 5. Recapitulation of Descriptive Completeness Scores at Cycle II

\begin{tabular}{clcc}
\hline $\begin{array}{c}\text { Score } \\
\text { Range } \\
\text { s }\end{array}$ & Criteria & $\begin{array}{c}\text { Frequenc } \\
\mathbf{y}\end{array}$ & $\begin{array}{c}\text { Percentag } \\
\mathbf{e}\end{array}$ \\
\hline$>75$ & Completed & 32 & $91,43 \%$ \\
$<75$ & Uncomplete & 3 & $8,57 \%$ \\
& d & 35 & $100 \%$ \\
\hline & Total & 35 \\
\hline
\end{tabular}

Based on the table 5 above, the completeness of students' learning results reached $91,43 \%$ and the minority of them who did not complete the minimum standard scores were $8,57 \%$. Data obtained after the treatment in the first cycle indicated that there were 32 students completed and only three uncompleted.

Based on the tabel 6 summary of descriptive data presented above, students' learning result which was completed was at 91,43\%. Among them, 10 students $(28,6 \%)$ were in the score range of $85-100$ (very good).22 students were in a good category $(62,9 \%)$, while the number of students who did not complete the minimum score was 3 which was $8,57 \%$ only. Students who were in the average category $(65-74)$ were $3(8,6 \%)$, but none of them in the low and very low categories.

Table 6. Recapitulation of Descriptive Categorization at Cycle II

\begin{tabular}{|c|c|c|c|}
\hline $\begin{array}{c}\text { Score } \\
\text { Ranges }\end{array}$ & Categories & Frequencies & Percentage \\
\hline $85-100$ & Very Good & 10 & $28,6 \%$ \\
\hline $75-84$ & Good & 22 & $62,9 \%$ \\
\hline $65-74$ & Average & 3 & $8,6 \%$ \\
\hline $55-64$ & Low & 0 & $0,0 \%$ \\
\hline $0-54$ & Very Low & 0 & $0,0 \%$ \\
\hline \multicolumn{2}{|c|}{ Total } & 35 & $100 \%$ \\
\hline
\end{tabular}

Observation sheet filled in by teachers in the cycle II provided data about the description of the activities when the learning was being carried out. It observed students' behavior during following the learning, and the availability of tools and facilities used for teaching.

The analysis of the assessment rubric in the second cycle showed that the students' learning result in the average had reached some targeted criteria. It showed that there was an increase in scores obtained by students. $91,4 \%$ of them were successful in cognitive, psychomotor, and affective aspects. Based on the indicators which had been priorly determined, in this case, at least $80 \%$ of students must complete those aspects, the second cycle was regarded to successfully implemented and had reached the set targets.

\section{Discussion}

Based on observation conducted during the implementation of the first cycle, we identified that 26 students were completing the minimum standardized scores $(74,29 \%)$, and 9 of them not $(25,71 \%)$. Then, we performed reflection based on the data obtained from observation to improve the students' learning result in the material of football in the next meeting.

Based on the observation and evaluation in cycle I, the learning output of students at Vocational High School 2 Makassar in the materials of football had not reached the target which should be at least $80 \%$ of students getting minimum $\geq 75$. The percentage of completeness obtained in the first cycle was $74,29 \%$. Meaning, there were 26 out of 35 students completed the minimum standard score. 
This was resulted by the lack of students' attention on the learning process causing them not totally understand the basic movements of football like feeding, holding, dribbling, and shooting. Besides that, during the learning process, students did not seem fully actively giving responds or questions about football, and they looked less confident and hesitant when practicing the games. Some students still made mistake in positioning their feet leading them to unsuccessfully perform feeding, unable to hold, and still used the tip of their feet to dribble, shot not on target and their bodies were still stiff so that the movement was not optimal.

In the second cycle, the researcher made another plan for the action to minimize some weaknesses in the cycle I. the researcher made a new lesson plan and observation sheet. The learning was still carried out using an inquiry learning model followed by 35 students but with different materials and test instruments.

After implementing the treatment in the second cycle, students got improvements on their scores which in this case, the percentage of score completeness was $91,43 \%$. When students were aware of their achievement in the first cycle, they were starting to be more enthusiastic to do every movement and perform it better. They seem better to understand the goals and purposes of learning football for their own.

$80 \%$ of the indicators which had been determined in this study was reached. In this case, 32 or $91,43 \%$ of students had got 75 and above (Good). Based on the planning, implementation, observation, evaluation, and reflection, it was concluded that this study had successfully achieved indicators and answered the research hypothesis from the implementation of an inquiry learning model that could improve the learning outcomes of football game learning at Vocational High School Negeri 2 Makassar students.

The study results conducted in cycles I and II indicated that the application of the Inquiry method had a good effect on improving the learning results of the Health Physical Education students especially on materials of the Volly Ball Technique. The students' learning outcomes reached $63.14 \%$. In cycle II, the student learning result increased from $63.14 \%$ to 83\% Tamren (2017: 37-38).

Based on this classroom action research, the inquiry learning model can be used as an alternative to overcome the low learning outcomes Dzikie \& Dwi Widjanarko, (2015: 86)
The explanation above shows that the application of the inquiry model was successful to improve student learning outcomes. This is supported by other research which shows that the application of guided inquiry learning models can improve students' learning outcomes in the aspects of knowledge on the concept of heat and displacement Noviana, (2017: 34).

\section{CONCLUSION AND SUGGESTION}

The inquiry learning model is a solution to improve the students' learning results of football material at Vocational High School 2 Makassar. The model is a creative strategy to support students to develop their talents independently leading to the emergence of synergy between students and teachers based on their respective roles.

The implementation of inquiry learning model is regarded to be effective to improve the learning results of students at the TKL 1 Grade $\mathrm{X}$ Vocational High School 2 Makassar. It is indicated by the results of cycle 2 in which there were 10 students $(28.6 \%)$ in the Very Good group, 22 students $(62.9 \%)$ in the Good scale, and 3 students $(8.6 \%)$ in the Medium scale. The grade completeness obtained at the end of cycle 2 was $91.43 \%$ and fulfilled the grade completeness.

It can be concluded that the implementation inquiry learning model can increase student learning outcomes in TKL 1 Vocational High School 2 Makassar. This was shown from the results of cycle 2 that there were 10 students $(28.6 \%)$ in the very good category, 22 students $(62.9 \%)$ on the good scale, only 3 students $(8.6 \%)$ categorized to be fair. The score completeness obtained at the end of cycle 2 was $91.43 \%$ and fulfilled the standard criteria.

Based on the implementation of the inquiry learning to increase the students' learning result of football material at Vocational High School 2 Makassar, there are some points to suggest as below: (1) The inquiry learning model can be taken as an alternative model that can be applied in teaching physical education especially in the materials of football in order to maximize students' learning outcomes. It can assist students not to only rely on material verbally delivered by teachers but they can also find out more information on their own; (2) In selecting a learning model, it is better to more focus on students so that they can more actively involve and not feeling bored in joining the 
class. Also, it can motivate students in learning so that it can increase the outcome. In applying the model, students' involvement is the main factor to make them more motivated in playing football; (3) By implementing the inquiry learning model, learning activities can be effective and efficient because students are not solely as object receiving the material, but also as the subject with the role to develop the model. As a result, the involvement of both teacher and student is very necessary for synergizing the inquiry learning model at Vocational High School 2 Makassar; (4) It is suggested to other researchers to develop and strengthen these research findings by carrying out further studies that can contribute to the improvement of the learning outcome or students' understanding of football.

\section{REFERENCES}

Aningsi. (2018). Penerapan Model Pembelajaran Inkuiri Untuk Meningkatkan Keaktifan Dan Hasil Belajar Siswa Pada Pelajaran IPA Materi Benda dan Sifatnya Di Kelas III SD Negeri Padurenan 04 Bekasi. Universitas Islam 45 Bekasi. Jurnal.unismabekasi. (Vol, 6 No. 1). hlm.50-58.

Aswar, A. (2018). Upaya Meningkatkan Hasil Belajar Menggiring Bola Pada Permainan Sepakbola Melalui Model Pembelajaran Inkuiri Siswa Kota Makassar. Sportive: Journal Of Physical Education, Sport and Recreation, 1(2), 36.

(https://doi.org/10.26858/sportive.v1i2.5 635, Diakses 04 September 2018).

Diah Nur Puspa F. (2018) Penerapan Pembelajaran Inkuiri dengan Media Gambar Berseri untuk Meningkatkan Aktivitas dan Hasil Belajar IPS Siswa Kelas iv SD Karangtengah Baru Kecamatan Imogiri Kabupaten Bantul. Universitas Negeri Surabaya. Jurnal Review Pendidikan Dasar. Jurnal Kajian Pendidikan dan Hasil Penelitian. (Vol 4, No 2). hlm. 1-11.

Dwi Ambarwati, (2017). Meningkatkan Hasil Belajar Siswa Melalui Model Pembelajaran Inkuiri Terbimbing pada Materi Sebaran Barang Tambang di kelas xi ips 1 SMAN 2 Probolinggo tahun ajaran 2016/2017. Universitas Negeri Malang. Jurnal Pendidikan Geografi. (Vol, 22. No. 2).Hlm. 76-84.

Dzikie Agung P \& Dwi Widjanarko, (2015). Penerapan Model Pembelajaran Inkuiri untuk Meningkatkan Hasil Belajar Siswa pada Kompetensi Memelihara Komponen Sistem Bahan Bakar Bensin. Universitas Negeri Semarang. Jurnal Pendidikan Teknik Mesin. (Vol, 15. No. 2) hlm. 82-86.

Handriani. (2015). Pengaruh model pembelajaran inkuiri terstruktur dengan pendekatan saintifik terhadap kemampuan berpikir Kritis dan hasil belajar fisika siswa. Universitas Mataram. Jurnal Pendidikan Fisika dan Teknologi. (Vol 1, No 3). Hlm. 210-220.

Handayani, (2016). Pengembangan Perangkat Pembelajaran dengan Pendekatan Saintifik Model Inkuiri Terbimbing untuk Meningkatkan Hasil Belajar IPA Siswa Kelas iv Sekolah Dasar. Pascasarjana Universitas Negeri Surabaya. Jurnal Review Pendidikan Dasar: Jurnal Kajian Pendidikan dan Hasil Penelitian (Vol 2, No 2). hlm 195-203.

Husdarta, J., \& Saputra, Y. M. (2014). Belajar dan Pembelajaran Pendidikan Jasmani dan Kesehatan (Vol. 1-2). Bandung: Alfabeta.

Juniarti Ika Dkk. (2017). Penerapan Model Pembelajaran Inkuiri Terbimbing Terhadap Self Efficacy dan Hasil Belajar Kimia pada Materi Koloid. Universitas Negeri Semarang. Journal of Innovative Science Education.(Vol, 6. No. 1) hlm 51-58.

Kumpas-Lenk, K., Eisenschmidt, E., \& Veispak, A. (2018). Does the design of learning outcomes matter from students' perspective? Studies in Educational Evaluation, 59, 179-186. https://doi.org/10.1016/j.stueduc.2018.0 7.008

Nurhaida, (2016). Penerapan Model Pembelajaran Inkuiri Dalam Upaya Meningkatkan Hasil Belajar IPA Siswa Kelas II SD Negeri 05 Kabawetan. 
Universitas Bengkulu. Jurnal PGSD: Jurnal Ilmiah Pendidikan Guru Sekolah Dasar. (Vol, 9. No. 3). hlm 301-307.

Nur Khosiah (2016). Penerapan Model Inkuiri untuk Meningkatkan Hasil Belajar Pokok Bahasan Kerja Sama NegaraNegara di Asia Tenggara pada Mata Pelajaran PKN bagi Siswa Kelas VI di SDN Tanjungrejo III Tongasprobolinggo. Pasca Sarjana Universitas Negeri Surabaya. Jurnal Review Pendidikan Dasar: Jurnal Kajian Pendidikan dan Hasil Penelitian (Vol. 2, No.2). hlm. 214-220.

Paizaluddin, \& Ermalinda. (2014). Penelitian Tindakan Kelas Panduan Teoritis dan Praktis (Vol. 1-2). Bandung: Alfabeta.

Rahmawati \& Rina. Penerapan Model Pembelajaran Inkuiri Untuk Meningkatkan Hasil Belajar IPA Siswa Kelas V SD Inpres 6/75 Ta' Kecamatan Tanete Riattang Kabupaten Bone. Universitas negeri Makassar. JIKAP PGSD: Jurnal Ilmiah Ilmu Kependidikan. (Vol, 1. No. 1) hlm. 4049.

Rosdiani, D. (2014). Perencanaan Pembelajaran Dalam Pendidikan Jasmani Dan Kesehatan (Vol. 1-2). Bandung: Alfabeta.
Rizka Anastasyia Y. (2017). Penerapan Model Inkuiri Untuk Meningkatkan Hasil Belajar IPA Siswa Kelas V SD. Universitas Pendidikan Indonesia. Jurnal Pendidikan Guru Sekolah Dasar. (Vol, 2. No. 3). hlm 26-37.

Sukardi. (2015). Metode Penelitian Pendidikan Tindakan Kelas Implementasi dan Pengembangannya (Vol. 1-3). Jakarta: PT Bumi Aksara.

Syafa'atin Noviana, Connie \& Dedy Hamdani. Penerapan Model Inkuiri Terbimbing untuk Meningkatkan Aktivitas, Hasil Belajar dan Keterampilan Berpikir Rritis Siswa Kelas x IPA.3 SMA Negeri 3 Bengkulu Tengah. Universitas Bengkulu Jurnal Pembelajaran Fisika. (Vol. 1, No. 1). hlm. 28-37.

Tamren (2017). Penerapan Metode Inkuiri Pada Mata Pelajaran Penjaskes Untuk Meningkatkan Motivasi Belajar Teknik Bermain Bola Volly Siswa Kelas Xi Ak 1 Smk Negeri 1 Meulaboh Tahun Ajaran 2016/2017. Jurnal umuslim. Volume 9, Nomor 1. hlm. 30-38.

Yusniati, (2017). Penerapan Model Pembelajaran Inkuiri Terbimbing Terhadap Hasil Belajar Pada Materi Laju Reaksi. Universitas Syiah Kuala. Jurnal Pendidikan Sains Indonesia (Indonesian Journal of Science Education). (Vol, 5. No.2) hlm. 1-9. 